\title{
TUTOR OPPIVAN RYHMÄN TUKENA
}

\author{
Alkuaan tutor syntyi yksilöiden oppimisen auttajaksi. \\ Opintokeskuksissa oppiminen on perinteisesti tapahtunut opintoker- \\ hoissa, joten on ollut luontevaa soveltaa tutortoimintaa myös oppivaan \\ ryhmään. Seuraavassa kerrotaan, millaisia kokemuksia ja mitä suuntavii- \\ voja ryhmätutoroinnin kehittämiseksi saatiin.
}

Ryhmässä yhdessä opiskeleminen tarkoittaa, että pieni joukko ihmisiä muodostaa ryhmän, jonka jäsenet yhteistyössä, yhdessä sovituin työtavoin oppivat jonkin yhdessä tavoitteekseen asettamansa asian tai taidon. Aloiteoikeus oppimiseen on ryhmällä itsellään. Perustana on vapaus ja omaehtoinen tehtävänhaku. Ryhmä ajaa itse omia etujaan, ja jäsenten toiminta perustuu keskinäiseen sopimukseen. Ryhmässä ei ole asiantuntijaopettajaa, vaan kaikki ovat keskenään samassa asemassa, vertaisia.

Onnistuneen ja tuloksellisen ryhmäoppimisen kulmakivinä ovat yhteiset ponnistelut ja jokaisen jäsenen oman merkityksen korostuminen lopputuloksessa. Yhdessä oppiminen perustuu kokemukseen, että yksilö tarvitsee toisia oppimisensa tueksi ja voi samalla olla avuksi toisten oppimisessa. Oppiminen tapahtuu vuorovaikutuksen välityksellä: toisia tarvitaan vastakaiuksi ajatuksille, omien ajatusten peiliksi ja puntariksi. Ajattelun ja tekemisen saavutukset ovat eduksi kaikille ryhmän jäsenille eivätkä olisi mahdollisia ilman jokaisen omaa osallistumista.

Yhteinen etu tarkoittaa, että ryhmän jokainen jäsen oppii. Ryhmä on itse vastuussa tästä. Siksi ryhmän täytyy osata kehittää tapansa työskennellä sellaisiksi, että kaikkien oppiminen on mahdollista. Usein se tarkoittaa työnjaollisia toimia, mutta ennenkaikkea tasavertaista vuoropuhelua, dialogia.
Oppivalla ryhmällä on kaksoistavoite: opittava asia ja ryhmän toimintaprosessiin liittyvä tunnetavoite. Ryhmällä on vastuu johtajuudesta, ryhmäkokemuksista oppimisesta, ryhmän kiinteydestä ja toimintansa arvioivasta kehittämisestä. Ryhmästä saatava, oppimista edistävä hyöty liittyy suurelta osin oppimisen tunnealueelle: oppimismotivaatio kasvaa, jäsenten käsitykset omasta oppimisesta vahvistuvat, itseluottamus ja tietoisuus omista vaikuttamismahdollisuuksista lisääntyvät. Suurimerkityksisiä ovat myös oletukset ja kokemukset sosiaalisten taitojen kehittymisestä: taito katsella asioita toisten näkökulmasta, luottamukselliset suhteet ja yhteistyökykyisyys.

Onnistuneiden oppimiskokemusten tuloksena opiskelijoiden maailma avartuu ryhmän ulkopuolelle. Turkulainen Timantit-ryhmä, joka tutki opinnoissaan työyhteisönsä henkistä hyvinvointia, kuvaa avartumista lehtihaastattelussa näin: " Ryhmämme kävi innokkaana lävitse opetuskokonaisuuteen kuuluneen kirjallisuuden. Seurasimme opiskelun sisältämiä aiheita lehdistöstä ja muista tiedotusvälineistä sekä haastattelimme omassa työyhteisössämme työntekijöitä. Uskoimme, että henkisen kasvun myötä pystymme hyödyntämään oppimamme parhaiten juuri valitsemamme aiheen piirissä. Toiveena oli myös saada tältä pohjalta kartoitettua henkilöstökoulutuksen tarvetta työyhteisössämme.” (Lehtinen 1995). 


\section{UUTTAKOULUTUKSESSA}

Itseohjautuvissa ryhmäopinnoissa on ainakin neljä oleellista seikkaa

1. Ihmiset itse päättävät organisoitua ryhmiksi ja käyttävät ryhmiä toteuttaakseen tarkoituksiaan ja parantaakseen elinolojaan.

2. Osallistumalla ryhmätoimintaan yksilö voi sekä kehittää itseään että muuttaa ympäristöään.

3. Ryhmä on yksilölle itsetuntemuksen lisäämisen väline, peili. Tietoinen, kriittinen suhde omaan toimintaan ja sen vaikutuksiin sekä uusia näkökulmia etsivä, tutkiva mieli kasvaa.

4. Oppiminen tapahtuu ja kehittyy toiminnassa.

\section{Ryhmät tarvitsevat henkistä tukea}

Opintokerhon on todettu muodostavan aikuisopiskelussa opiskelijoille sellaisen oppimisympäristön, joka tukee oppimista ja edistää siihen osallistuvien ihmisten itsetunnon ja itsevarmuuden kasvua. KSL- ja TSL-opintokeskusten yhteisen Sopimisopiskelu opintokerhossa -kokeilun päätuloksia oli, että osanottajien käsitykset itsestään oppijoina muuttuivat positiivisiksi (Korhonen \& Puro 1992). Kokeilusta selvisi myös, että vaativissa pitkäkestoisissa opinnoissa ryhmien oppimista voitaisiin edistää ulkopäin tulevan tuen ja neuvonnan avulla. Siitä sai alkunsa opintokerhojen tutortoiminta ja opintokeskusten henkilöstön koulutushankkeet kohti oppimisen auttamisen ammattilaisuutta.

Tutoroinnin periaatteita ovat (Hakanen \& Puro 1995, 47-49):

1. auttaa oppijaa ja oppivaa ryhmää tekemään itse

2. kannustaa ja innostaa

3. johdattaa tietolähteille

4. auttaa vaikean paikan yli

5. antaa palautetta ja

6. olla yksilön ja koko ryhmän tukena.

Ryhmän tutorin on ymmärrettävä yksilöiden käyttäytymisen ja oppimisen lisäksi ryhmän toimintaa, jotta hän osaa suhteuttaa ryhmässä esiintyviä ilmiöitä ryhmän "luonnolliseen” kehittymiseen. Tutorin pitää ymmärtää konfliktien, klikkiytymien tai sokean ryhmäkoheesion taustoja ja syitä. Lisäksi ryhmän tutorin on osattava muuttaa omaa rooliaan ja tehtäviään ryhmän kehitysvaiheiden mukana.

On todennäköistä, että ryhmän alkutaipaleella tutor on melko ohjailevakin, mutta ryhmän kypsyessä tutorin rooli muuttuu enemmän reflektoivaksi palautteen antajaksi. Luonnollisesti yksittäisten oppijoidenkin tutorin täytyy tuntea yksilön kehittymistä, mutta yksilöiden tutoroinnista puuttuu kokonaan ryhmäkehityksen näkökulma. Tiivistäen voisi todeta, että henkilökohtainen tutor on "psykologi" kun taas ryhmän tutor on "sosiaalipsykologi". Toki tutorin on tunnettava (sosiaali)psykologisen tietämyksen lisäksi oppimiseen ja koulutukseen liittyviä kysymyksiä. Tärkeintä kuitenkin on, että tutor on henkilö, jonka luo on helppo mennä ja joka osaa kuunnella.

\section{Dialogi on tutorin työväline}

Dialogista on kirjoitettu viime aikoina varsin paljon (mm. Lehtovaara \& Jaatinen 1994) ja erityisesti oppivan organisaation yhteydessä (mm. Senge 1990, Laitinen ym. 1996). Dialogin tarkastelu on kuitenkin varsin teoreettista tai filosofista. Tämä johtunee dialogi-teeman vaikeudesta ja moniaineksisuudesta. Tarvitaan dialogia konkretisoivaa tarkastelua. Olisi pystyttävä siirtymään sinänsä arvokkaista ja perustelluista teoreettisista oletuksista käytännön dialogiin: Miten dialogi saadaan onnistumaan? Millaisia taitoja dialogissa tarvitaan? Kuinka dialogiin voidaan harjaantua?

Onnistuneen dialogin ehtoina voidaan pitää Habermasin esittämiä yhteisymmärryksen ehtoja (Kangas 1987, 38-43):

1. Totuus. Dialogissa tulee esittää tosiasioita.

2. Oikeellisuus. Puhujan toiminta on sosiaalisesti hyväksyttyä ja oikeutettua.

3. Totuudellisuus. Puhuja ilmaisee itseään rehellisesti.

4. Ymmärrettävyys. Asiat tulee esittää siten, että toiset ymmärtävät viestin. Sanoihin sisältyy hyvin erilaisia merkityksiä, joten dialogissa on huolehdittava, että jokainen osallistuja tulee oikein ymmärretyksi. 
Hyvä ja onnistunut dialogi on myös kekseliästä, hauskaa, kriittistä ja avointa. Dialogi liittyy saumattomasti reflektioon (Friedman 1995). Onnistunut dialogi edistää ryhmän reflektiivisiä prosesseja ja oppimista. Tutortoimintaan sopii erityisen hyvin Sokrateen ajatus dialogista, kun hän sanoi itse toimivansa henkisenä kätilönä. Sokrateen tavoin tutorikaan ei itse synnytä, vaan tukee ja auttaa ryhmää synnyttämään.

Olisi löydettävä keinoja dialogin käytännön toteuttamiseen ja harjoittelemiseen. Kysymys on siitä, kuinka tutor onnistuu olemaan henkinen kätilö:

- Dialogin osallistujat tarvitsevat taitoja: keskittyminen ja kuunteleminen, sanominen, perusteleminen, kysyminen.

- Taidot ovat opittuja, joten niitä voidaan kehittää. Tutor voi opastaa ja olla itse esimerkkinä.

- Kaikki dialogin osallistujat ovat tasavertaisia. Tasavertaisuuden pitää olla läsnä kaikessa toiminnassa, kuten puheenvuorojen määrässä ja kuulluksi tulemisessa.

- Edistääkseen dialogia tutorin pitää etsiä oikeita kysymyksiä ja rohkaista ryhmän jäseniä kysymysten etsimiseen. Vastauksiakin tärkeämpää on olennaisten kysymysten löytäminen.

- Tutorin on pidettävä mielessään ja muistutettava ryhmää siitä, että ryhmässä pitää olla erilaisia mielipiteitä. Olennaista on, miten ne perustellaan, ei se, kuka ne esittää.

- Tutorin on pysyteltävä taka-alalla. Hän ei johda dialogia, vaan johdattaa vuoropuheluun.

- Tutorin on erityisesti ja aina asetuttava tukemaan ujointa jäsentä ja raivattava hänelle tilaa ryhmässä.

Tutorin ja ryhmän välinen suhde on dialoginen. Se luo perustan onnistuneelle ja tuloksekkaalle yhteistyölle ja yhteisvoimin oppimiselle.

\section{Aikuinen ja työ -opinnot tutorin harjoittelukenttänä}

Aikuinen ja työ eli At-opinnot on Työväen Sivistysliiton (TSL), Kansan Sivistystyön liiton (KSL) ja Suomen Ammattiliittojen Keskusjär- jestön (SAK) toteuttama pienryhmille tarkoitettu monimuoto-opiskeluohjelma. Opintojen laajuus on 9 opintoviikkoa. Opintojaksot liittyvät sisällöllisesti työelämään ja työelämässä tarvittaviin taitoihin.

At-opintojen pituus on ollut noin kaksi vuotta, mutta usein opinnot ovat venyneet aiottuja pidemmiksi, mihin on vaikuttanut vaikeaksi ja mittavaksi koettu lopputyö. Siinä ryhmä selvittää jotain oman työpaikkansa ongelmaa itsenäisesti tietoa hankkien ja käsitellen. Lopputyön aiheita ovat olleet muutoksen hallinta ja vastuun ottaminen työelämässä, työtyytyväisyys, paikallinen edunvalvonta ja henkinen hyvinvointi. Ongelma, mihin useimmin on tartuttu, on työpaikan vaikeat ihmissuhteet.

At-opintojen anti ja tulokset ovat olleet rohkaisevia. Osaltaan tästä jo kertoo lopputöiden aiheet ja niihin vaadittavat työpanokset. Myös opiskelijoiden arviot omasta oppimisesta ovat olleet erittäin positiivisia:

"Toisten ihmisten ymmärtäminen on lisääntynyt."

"Ryhmätyötaidot lisääntyneet."

"Olen mieleltäni avartunut, luotan itseeni ja rohkenen esittää ajatuksiani."

"Innostuin aloittamaan päätoimiset opinnot uudelleen."

“Tiedonjanoni päivittäisessä elämässäni on kasvanut."

At-opintojen pääasiallisia opiskelu- ja oppimismenetelmiä ovat oppimateriaaleihin perehtyminen, tehtävien ja harjoitusten tekeminen ja ryhmäkeskustelut. Tällaisissa menetelmissä korostuu etäopettajien ja tutorin rooli. Etäopettajat ovat opintojaksokohtaisia eli ryhmällä on opintojensa aikana monia etäopettajia. Sen sijaan ryhmän tutor pysyy samana koko opintojen ajan, joten ryhmän ja tutorin välille muodostuu parhaimmillaan tiivis suhde. Useimmat ryhmät ovat pitäneet tutoria välttämättömänä opintojen läpiviemiseksi, mikä tulee varsin selvästi ilmi opiskelijoiden kommenteista:

"Tutori on selkäranka ja käynnistysmoottori."

"Jos tutoria ei olisi ollut, niin opinnot olisin 


\section{UUTTAKOULUTUKSESSA}

lopettanut ja hän on ollut erittäin

kannustava."

"Antoi hyvin tietoa mistä hakea lisätietoa aineistoon."

On syytä muistaa, että At-opiskelijat ovat useimmiten tottumattomia opiskeluun, joten opiskelijat ja ryhmät tarvitsevat tutorin tukea erityisesti opintojen alkuunsaattamisessa sekä opiskelutaitojen kehittämisessä. Koska tutorin ja ryhmän välinen suhde on useimmiten varsin tiivis, ilmaantuu tutorin ja ryhmän välille toisinaan myös ongelmia. Tämä on kuitenkin luonnollinen ilmiö, kun ihmiset ovat tiiviisti tekemisissä. Yhdenkään ryhmän opiskelu ei ole loppunut tutorin ja ryhmän välisiin ristiriitoihin. Keskeyttämisten taustalta löytyy ennen muita osanottajien elämäntilanteiden muutoksia.

Aikuinen ja työ -opintokerhojen menestyminen liittyy läheisesti tutorin toiminnan onnistumiseen. Poikkeuksetta ryhmät ovat kertoneet, että tutor on ollut turvallisuuden tunteen antaja koko opiskelun ajan. Pelkkä tieto siitä, että apua on tarjolla, on vapauttanut ryhmää.

Mitä tutoreille itselleen tapahtuu oppimisprosessien aikana, on jäänyt yksittäisiin havaintoihin ja kommentteihin. At-opintojen kokeiluvaiheen aikana tutorit pitivät oman oppimisensa päiväkirjaa. Tarkoituksena oli seurata, reflektoida ja dokumentoida kehitystä. Päiväkirjan pitäminen havaittiin hyödylliseksi mutta hankalaksi. Eräistä muistiinpanoista ilmenee, että yksi tutorin oman kehittymisen päähuolista liittyy opiskelijoiden ja tutorin välisiin suhteisiin. Tutor toivoo, että suhde muodostuisi vapaaksi vuoropuheluksi ja kanssakäymiseksi. (Korhonen \& Puro 1992)

Ongelmaksi on kuitenkin osoittautunut, että sekä tutor itse että opiskelijat odottavat tutorin käyttäytyvän opettajan tavoin. Opettamisesta eroava tutorin ammattitaito on vielä hakusalla. Sama päiväkirjan kirjoittaja toteaa hyvin vaikeaksi tehtäväksi sen, miten ryhmää autetaan auttamaan sen yhtä jäsentä. Ryhmän pitäisi innoittaa jäseniään ja tutorin koko ryhmää tähän. Tämän tutorin kasvun päämääränä oli Maria Montessorilta peräisin oleva ajatus: Auta minua tekemään se itse.

Myös Liikealan ammattiliitto on kouluttanut kaupanalan työpaikkojen kehittämisryhmien tueksi omat tutorinsa. Tavoitteena on kehittää työpaikoille jäsenistön omista toiveista ja tarpeista nousevaa työpaikkaa kehittävää ryhmätoimintaa ja lisätä siten työntekijöiden taitoja ratkoa ongelmatilanteita itsenäisesti. Tärkeää on saada jäsenet toimimaan oma-aloitteisesti. Eräs tässä toiminnassa ansioitunut tutor kuvaa kehitystään tutoroinnin ammattilaiseksi näin: “ Osaan katsoa tilanteita neutraalisti, vaikka tuntuisi pahalta. Olen saanut rohkeutta ja uskallusta, voin olla oma itseni. Enää ei ole tarvetta mennä mukaan porukan voivotteluihin ja valitteluihin. Lisäksi olen oppinut utelemaan asioita eri kantilta." (Suorsa 1996). Puheenvuoro kertoo reflektoivan ajattelun kehittymisestä.

TSL:n uusin monimuotokoulutusohjelma, Selkis! -opinnot, painottuu aiempaa enemmän tutorin varaan. Selkis! -opinnoissa oppiva ryhmä tutkii itseään kiinnostavaa asiaa. Opinnoissa ei ole ennalta määrättyä sisältöä, ainoastaan portaittain kehittyvä prosessi. Prosessiopiskelun malli on varsin läheinen tutkivan opintokerhon idealle. Tutkivassa prosessiopiskelussa tutorin rooli ryhmän tukihenkilönä korostuu.

\section{Mistä ammentaa tutorin ammatin teoriaa?}

Tutortoiminnan teoreettinen tausta on helpointa sijoittaa kasvatustieteen sisälle. Tutortoimintaan sisältyy kuitenkin aineksia monista muistakin tieteenaloista, joten on perusteltua todeta, että tutortoiminta on teoreettiselta perustaltaan poikkitieteellistä. Luonnollisesti tutortoiminnassa korostuu kasvatustieteellinen näkökulma, mutta merkittäviä ovat myös sosiaalipsykologinen ja viestintäteoreettinen viitekehys. Tutortoiminnan teoreettinen pohja on siis jossain mielessä ongelmallinen, koska sitä ei voida lokeroida yhden tieteen sisään, vaan olisi omaksuttava laaja-alaisempi teoriakehys. 
Oppimisen ohjauksessa erityisen tärkeitä ovat sosiaaliset taidot, kuten avoimuus, vastuullisuus ja ratkaisukeskeisyys. Sosiaalisia taitoja ovat myös viestintätaidot. Tutorin on erityisesti osattava kuunnella, mutta luonnollisesti myös puhua, perustella ja kysyä. Myös oppimistaidot ovat olennaisia tutorin toiminnassa. Tutorin on itsekin osattava oppia, ei riitä, että hän osaa ohjata ryhmää oppimaan. Sosiaalisten, viestinnällisten ja oppimistaitojen lisäksi tutorin on osattava tiettyjä käytännöllisiä taitoja, kuten tietotekniikan hyödyntämistä ja kirjaston käyttöä.

Tutorin ammattitaidon kehittämiseksi TSL:ssa toteutettiin ns. tutorhanke, jossa 21 henkilöä opiskeli turoriksi. Tavoitteena oli muodostaa tutoreiden verkko, sillä asiantuntijuus syntyy ja kehittyy sosiaalisissa verkostoissa ja ihmisten välisissä kohtaamisissa (Launis 1995). Tutor ei siis ole yksinäinen ammattitaidon opiskelija, vaan ammattitaito ja asiantuntijuus tehdään yhteistoiminnalla. Lisäksi verkko tarjoaa tutoreille tukea ja apua. Verkon muodostamisessa hyödynsimme telematiikkaa, koska tutoreiden maantieteelliset etäisyydet ovat melko pitkät. Opiskelu tutorhankkeessa oli monimuotoista eli hankkeessa on lähi- ja etäopiskelua sekä käytännöllistä ryhmän tutorina toimimista. Tutorin opintojen laajuus on 8,5 opintoviikkoa, minkä lisäksi kukin sai suorittaa lisäjaksoja tarpeensa mukaan. Yhteisiä opintojaksoja olivat tutortoiminta, pienryhmäopiskelu, oppimaan oppiminen, kouluttajavalmiudet sekä viestintäja vuorovaikutustaidot.

\section{Tutortoiminnan kriittistä tarkastelua}

Tutortoiminnan ongelmakohdat kiteytyvät kokemustemme pohjalta kysymykseen,

kuinka tutortoiminta ja itseohjautuvuuden periaate sopivat yhteen? Nähdäksemme oppimisen itseohjautuvuus on luonteeltaan sekä ulkoaettä sisältäpäin ohjautuvaa. Tällöin tutor on luonteva osa ryhmän oppimista. On kuitenkin oltava tarkka sen suhteen, että ulkoaohjautuvuuden eli tutorin osuus ei nouse liian hallitsevaksi ryhmän toiminnassa. Itseohjautuvuudessa on hyväksyttävä se tosiasia, että ihminen tar- vitsee toisia ihmisiä niin oppimisessa kuin muussakin elämässä. Täydellinen itseohjautuvuus on täysi mahdottomuus eli sitä ei voi pitää tavoittelemisen arvoisena.

Miten estää tutorin ja ryhmän keskinäisriippuvuus? Kenellä on vastuu toiminnasta ja oppimisesta, koko ryhmällä, ryhmän avainjäsenillä vai tutorilla? Tutorin on periaatteessa tehtävä itsensä tarpeettomaksi ryhmän oppimisen kannalta, mutta käytäntö on osoittanut, että joissakin tapauksissa ryhmän ja tutorin välille muodostuu riippuvuussuhde. Tällainen suhde ei ole tutortoiminnan tarkoitus eikä edistä ryhmän omaehtoista oppimista. Riippuvuussuhteen muodostuminen liittyy läheisesti vastuuseen. Tutor on saattanut ottaa liian suuren vastuun ryhmän toiminnasta, jolloin ryhmä ja tutor eivät tavallaan pääse irti toisistaan. Vastuukysymys liittyy myös ryhmän keskinäisen työnjakoon. Käytäntö on soittanut, että ryhmissä on toisinaan "siivellä eläjiä" eli kaikki eivät osallistu yhtä paljon työskentelyyn ja oppimiseen. Tästä seuraa myös se, että kaikki eivät opi yhtä paljoa. Vastuun ja oppimisen kasautuminen on kuitenkin tosiasia, jota ei voi täysin välttää.

\section{Lopuksi}

Tutortoiminnan haaste liittyy sekä yksilö- että järjestelmätasoon. Yksilötasolla tutortoiminta edellyttää uutta poikkitieteellistä osaamista, missä opetuksen piiriin nousee opiskelijan oman sisäisen varmuuden vahvistuminen ja sosiaalisen kasvun haaste. Kasvun merkki on tunne siitä, että toiset ymmärtävät minua ja minä toisia aikaisempaa paremmin.

Järjestelmätason ongelmat liittyvät oppimis- ja toimintakulttuuriin. Tutortoiminta edellyttää ajattelu- ja toimintatapojen muutosta sellaiseksi, että kouluttamisen ja opettamisen sijasta korostuu oppiminen ja oppimiseen ohjaaminen. Tutortoiminta on oppimiskulttuurissamme uusi elementti, joka luo edellytyksiä todelliselle ryhmien itseohjautuvuudelle ja elinikäiselle oppimiselle. Kyseessä on subjektiksi, tekijäksi kasvu. 


\section{UUTAKOULUTUKSESSA}

Subjektiksi kasvulla on yhteiskunnallinen ulottuvuutensa. Yhteiskuntamme edellyttää jäseniltään yhä itseohjautuvampaa ja aktiivisempaa toimintaa oman elämänkaarensa ja identiteettinsä rakentamiseksi. Tutortoiminta omalta osaltaan tukee tätä kehitystä.

Ryhmien ohjauksella on yhtymäkohtia myös työelämän kehitykseen. Tutorit voivat ratkaisevasti tukea tiimien toimintaa ja oppimista. Se edistää nykypäivän ja enenevästi tulevaisuuden työelämän kvalifikaatioita: sosiaalisia taitoja, oppimaan oppimista ja itseohjautuvuutta.

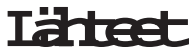

FRIEDMAN, S. (1995) The Reflecting Team in Action. New York: The Guilford Press.

HAKANEN, J. (1995) A classroom without walls and teachers. 27th Meeting in Finland Seminar.
HAKANEN, J. \& PURO, U. (1995) Tutortoiminnan opas. Helsinki: TSL-opintokeskus.

KANGAS, R. (1987) Jürgen Habermasin kommunikativivi sen toiminnan teoria. Helsinki: Tutkijaliiton julkaisusarja 45.

KORHONEN, L. \& PURO, U. (1992) Gurut pois ja kirja käteen. Sopimusopiskelu opintokerhoissa. Kokeilun loppuraportti. KSL-opintokeskus \& TSL-opintokeskus.

LAITINEN, M., VARTIAINEN, M. \& PULKKIS, A. (1996) Ryväskehittäminen oppivan organisaation menetelmänä. Aikuiskasvatus 2, 93-103.

LAUNIS, K. (1995) Asiantuntijoiden ybteistyö perusterveydenhuollossa. Stakes, tutkimuksia 50.

LEHTINEN, H. (1995) Määrärabaleikkankset murentavat työntekijän henkistä hyvinvointia. Valtti 3/1995.

LEHTOVAARA, J. \& JAATINEN, R. (1996)(toim.) Dialogissa - matkalla mabdollisuuteen. Tampere: Tampereen yliopiston opettajankoulutuslaitoksen julkaisuja A 21.

MATIKAINEN, J. (1996) Kysely At-opiskelijoille. TSL-opintokeskus.

SENGE, P. M. (1990) The Fifth Discipline: The Art \& Practice of The Learning Organization. New York: Doubleday Currency.

SUORSA, B. (1995) Painopiste jäseniin. Palkkatyöläinen. 